\title{
Technical and Economic Evaluation of a Small-Scale Wind Power System Located in Berlin, Colombia.
}

\author{
Evaluación Técnica y Económica de un Sistema de Generación de Energía Eólica a Pequeña \\ Escala Localizado en Berlín, Colombia
}

\author{
María de los Ángeles Pinto Calderón ${ }^{1}$, Jennyffer Katerine Moreno Calderón ${ }^{1}$, Yecid Alfonso Muñoz \\ Maldonado $^{1}$, Adalberto Ospino Castro ${ }^{2}$ \\ ${ }^{1}$ Universidad Autónoma de Bucaramanga (UNAB), Bucaramanga, Colombia \\ ${ }^{2}$ Universidad de la Costa (CUC), Barranquilla, Colombia
}

\begin{abstract}
This work evaluates the possibility of increasing the national and regional competitiveness from the local generation of energy in Berlin - Santander, based on a technical and economic feasibility assessment of a small-scale wind energy generation system. Despite the important growth wind energy in Colombia has acquired over the last years, there is still a very limited number of investigations and projects. For the Andean region of Colombia there is a considerable lack of academic or industrial projects that address this topic. Hence, the importance of the study lies down in the potential explored for an environment that had not yet been addressed and may become determinant for the technological and academic advancement in the wind energy knowledge for the country. The study is conducted from a database provided by the Institute of Hydrology, Meteorology and Environmental Studies (IDEAM) at a meteorological station located in Berlin-Santander. The available wind potential is calculated for the climatic conditions of 2015. Three different Wind Energy Conversion Systems (WECS), $1 \mathrm{~kW}, 3 \mathrm{~kW}$ and $900 \mathrm{~kW}$, are technically compared to determine the best option for the given conditions. Finally, a brief economic evaluation is carried out to determine the economic viability of the project and lay the groundwork for further investigations.
\end{abstract}

Keywords: Andean Region, Wind Energy, Wind Potential.

\section{Resumen}

Este trabajo evalúa la posibilidad de aumentar la competitividad nacional y regional a partir de la generación in situ en Berlín - Santander basado en una evaluación de factibilidad técnica y económica de un sistema de generación de energía eólica a pequeña escala. A pesar del importante crecimiento que la energía eólica en Colombia ha adquirido en los últimos años, aún existe un número muy limitado de investigaciones y proyectos. Específicamente, para la región andina de Colombia existe una considerable falta de investigaciones académicas o empresariales que aborden este tema. Así pues, la importancia de este estudio radica en el potencial explorado para un entorno que no se ha abordado y puede llegar a ser determinante para el avance tecnológico y académico en el conocimiento de la energía eólica para el país. El estudio se realizó a partir de una base de datos proporcionada por el Instituto de Hidrología, Meteorología y Estudios Ambientales (IDEAM) en una estación meteorológica ubicada en Berlín-Santander. El potencial eólico disponible se calculó para las condiciones climáticas de 2015. Tres turbinas eólicas diferentes, $1 \mathrm{~kW}, 3 \mathrm{~kW}$ y $900 \mathrm{~kW}$, se compararon técnicamente con el objetivo de determinar la mejor opción para las condiciones dadas. Finalmente, se llevó a cabo una breve evaluación económica para determinar la viabilidad económica del proyecto y sentar las bases para futuras investigaciones.

Palabras claves: Región Andina, Energía Eólica, Potencial Eólico.

*Corresponding Author.

E-mail: mpinto12@unab.edu.co
How to cite: Pinto, M. P., Moreno, J. K., Muñoz, Y. A., Ospino, A., Technical and Economic Evaluation of a Small-Scale Wind Power System Located in Berlin, Colombia, TECCIENCIA, Vol. 13 No. 24, 63-72, 2018

DOI: http://dx.doi.org/10.18180/tecciencia.2018.24.7 


\section{TECCIENCIA}

\section{Introduction}

The landscape of energy is in constant change. The growth of the pro-environment idiocrasy over the political scenario, global warming, the inevitable shortage of fossil fuels, political and social conflicts in the large oil producers, taxes for fossil fuels and cuts in the supply has created a great volatility in the fossil fuel prices with a strong tendency towards higher prices [1] [2]. Considering the various factors that influence the current panorama, especially the fossil fuels, renewable energies are taking place as the most reliable sources of energy for the future, evidence of this is the exponential growth in academic articles, projects and installed capacity over the lasts years [3].

Currently, Colombia counts with very few operational power generation plants for non-conventional renewable energy systems (NCRE), this can be explained due to the large availability of water resources, and a lack of regulations and incentives for NCRE. Historically, Colombia has been highly dependent of the cheap hydraulic power which currently contributes with about $69,93 \%$ of the national generation [4]. Nevertheless, due to the great impact that climatic phenomena, such as El Niño or La Niña, have on the hydraulic generation [5] it has become necessary to explore new technologies and energy sources which can meet the needs of the country without compromising the ability of future generations to supply theirs.

According to IDEAM [3], an alternative that has been widely evaluated for the Caribbean region is the wind energy systems, being the Jepirachi wind farm the most highlighted of all with an installed capacity of 19,5 MW and located in the department of La Guajira. However, other regions also have been mostly left aside by the industry and the academy even when there is an appreciable theoretical potential which can be exploited for energy generation.

This study is developed with the objective of evaluating the viability of wind generation systems in the Andean region and aiming for small-scale wind power systems. In Colombia multiple studies have been carried out determining that the Caribbean region, and more specifically the department of La Guajira, is the best option for largescale wind farms [3].

However, distributed generation is becoming one of the most studied options for the future of the energy, as it presents itself as an autonomous system constituted by several small-scale generators distributed between various users of the grid [6]. The approach of smart grids and distributed generation for small communities presents an opportunity for small-scale NCRE, as in this case, wind power.
The Andean region is constituted mainly by mountainous areas, which in many cases represent geographic and logistical challenges for the transport of energy. The possibility of installing small-scale NCRE based systems which can meet the energy demand of small communities in remote areas, taking advantage of their own energy potentials; become one of the most important and necessary studies for the development, not only of the energy sector, but of national competitiveness and energy security for all the communities of the country.

This paper has been built to display the technical and economic considerations for small-scale wind generation system in Berlin-Santander (Andean Region). Also, sets out the considerations that are necessary for the selection of the different components of the wind power generation system. Finally, this paper looks up to set the ground for further investigations on small-scale wind power generation for the Andean Region.

\section{Methodology}

This paper considers two aspects for the evaluation of a Small-scale wind power system in Berlin-Santander as shown in Figure 1. The technical evaluation refers to all the geographical, climatological, mechanical and mathematical aspects which can influence in the behavior of the WECS. Once described the behavior of the different turbines, the technical evaluation looks up to determine the best option for the project, according to their performance. Then, a brief economic evaluation is realized to determine the viability of the project based on the system costs and the revenue from the sale of the energy.

\subsection{Technical aspects}

First, this study determines if the wind potential of Berlin is suitable for energy harvesting.

\section{TECHNICAL EVALUATION}

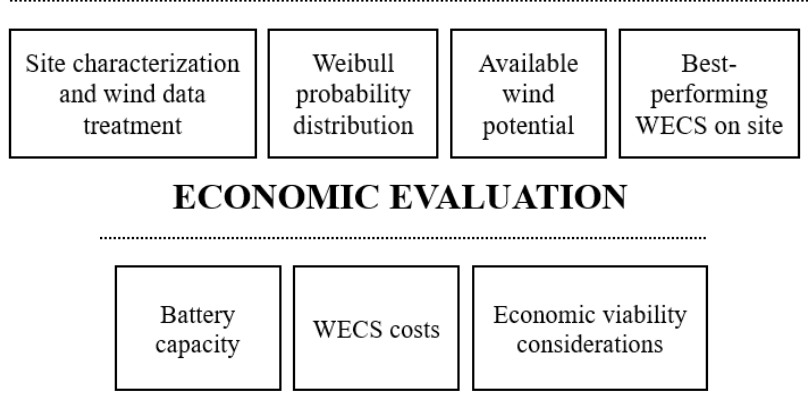

Figure 1 Methodology of the study 


\section{TECCIENCLA}

From this point several assumptions are made in favor of further investigations. The wind farm is constituted by only one (1) single WECS, which is chosen between three different options based on very low, low and medium power output, $1 \mathrm{~kW}, 3 \mathrm{~kW}$ and $900 \mathrm{~kW}$, respectively. The chosen turbine is determined by its efficiency at the given conditions.

Hence, the available wind potential of Berlin is given by the Weibull function; and, the conditions that determine the WECS are the power curve and the relative frequency

\subsubsection{Site characterization and wind data treatment}

The first approach to any analysis is to define the conditions of the location. For this study the principal and most useful data are: Altitude, Temperature and wind Speed. For any wind power study, one of the most important variables is the wind speed, understanding it as a very fluctuating variable, it is needed to be treated as a matrix of data and not a single datum. In order to obtain both, wind potential and the Weibull function from the wind speeds it is needed to find first the frequencies of the velocities.

Wind speed matrix must be classified according to the frequency of occurrence for each velocity. Depending on the database, each author can determine an interval of data according to his criteria. In general, while shorter the interval better the information obtained. For this study intervals are each $0,2 \mathrm{~m} / \mathrm{s}$, starting at $1,2 \mathrm{~m} / \mathrm{s}$ as this is the minimum value registered in the database.

The occurrence frequency of the wind speed is the number of times a given datum in the matrix e.g. $2,3 \mathrm{~m} / \mathrm{s}$, occurs in the total number of data e.g. 3 times, this value is known as absolute frequency, or simply as frequency; if the absolute frequency is divided by the total number of data e.g. 3 times/365 data, then it is known as Relative frequency [7]. If the Relative frequency $\mathrm{f}$ is multiplied by the datum in the matrix v, e.g. $2,3 \mathrm{~m} / \mathrm{s} * 3$ times $/ 365$ data, it is a common formula known as $\mathrm{V} * \mathrm{f}$ from which is obtained the average wind speed and the standard deviation for the matrix.

\subsubsection{Weibull function}

The Weibull function is a two (2) parameter function used to estimate wind speed frequency distribution [8]. The Weibull distribution depends of a shape parameter (k), also known as the Weibull slope, which indicates the dispersion of the data of the speeds [9]-[11], therefore:

$k=\left(\frac{\sigma}{\bar{V}}\right)^{-1,086}$

Here $k=$ Shape parameter $(-), \sigma=$ Standard deviation $(\mathrm{m} / \mathrm{s})$ and $V=$ Average wind speed $(\mathrm{m} / \mathrm{s})$.
In case that a wind database is not available, it is possible to work with an average speed using the Rayleigh distribution, being this a case of the Weibull distribution where $k=2$.

The scale parameter $(A)$ indicates the average speed at the location of study [9] [11], it is used as indicated in eq. ¡Error! No se encuentra el origen de la referencia.

$$
A=\frac{\bar{V}}{\Gamma *\left(1+\left(\frac{1}{k}\right)\right)}
$$

Here $A=$ Scale parameter $(\mathrm{m} / \mathrm{s}), V=$ Average wind speed $(\mathrm{m} / \mathrm{s}),=$ Gamma function $(-)$ and $k=$ Shape parameter $(-)$.

Finally, the probability of occurrence of certain velocity is given by Weibull probability density function [9] [12].

$$
f(v)=\frac{k}{A} *\left(\frac{v}{A}\right)^{k-1} * \exp \left[-\left(\frac{v}{A}\right)^{k}\right]
$$

Here $f(v)=$ Weibull probability for each wind speed $v(-), k=$ Shape parameter (-), $A=$ Scale parameter $(\mathrm{m} / \mathrm{s})$ and $v=$ Wind speed $(\mathrm{m} / \mathrm{s})$.

\subsubsection{Available wind potential}

The potential wind power density, $\mathrm{Pv} / \mathrm{A}$, available on a unit area oriented normal to the wind of speed $\mathrm{v}$ is represented by eq. (4) [9].

$$
\frac{P_{v}}{A}=\frac{1}{2} * \rho^{*} v^{3} * f(v)
$$

Here $P_{v} / A=$ Wind power density of each wind speed $v$ $\left(\mathrm{W} / \mathrm{m}^{2}\right), \rho=$ Density $\left(\mathrm{kg} / \mathrm{m}^{3}\right), v=$ Wind speed $(\mathrm{m} / \mathrm{s})$ and $f(v)$ $=$ Weibull probability for each wind speed $v(-)$.

Eq. (4) uses density as one of the variables needed to find the wind power density. Nevertheless, using density of air at normal conditions $\left(1,225 \mathrm{~kg} / \mathrm{m}^{3}\right)$ will result in misleading information. Hence, eq. (5) corrects the density based on the altitude and temperature of the location [9].

$\rho=\rho_{0} * e\left(\frac{z}{8435}-\frac{T-15}{288}\right)$

Here $\rho=$ Density $\left(\mathrm{kg} / \mathrm{m}^{3}\right), \rho_{0}=$ Reference density $\left(\mathrm{kg} / \mathrm{m}^{3}\right), Z$ $=$ Altitude (masl) and $T=$ Average temperature $\left({ }^{\circ} \mathrm{C}\right.$ ). Available wind potential $\mathrm{Pa} / \mathrm{A}$ is determined by the 


\section{TECCIENCLA}

summation of all the given wind power density P/A for each wind speed.

$$
\frac{P_{a}}{A}=\sum_{v=1}^{k} \frac{P_{v}}{A}
$$

Here $P_{a} / A=$ Available wind potential $\left(\mathrm{W} / \mathrm{m}^{2}\right), v=1=$ Minimum wind speed value $(\mathrm{m} / \mathrm{s}), v=k=$ Maximum wind speed value $(\mathrm{m} / \mathrm{s})$.

As explained by J. Manwell et al. [13], the criteria classification of the available wind potential is a highly recommended way to determine the feasibility of a specific place for which $P_{a} / A$ is known. Table 1 shows the criteria for selection.

Table 1 Classification of the available wind potential [2].

\begin{tabular}{ll}
\hline \multicolumn{1}{c}{ Parameter } & Criterion \\
\hline \hline$P_{a} / A<100 \mathrm{~W} / \mathrm{m}^{2}$ & Poor \\
$P_{a} / A \approx 400 \mathrm{~W} / \mathrm{m}^{2}$ & Good \\
$P_{a} / A>700 \mathrm{~W} / \mathrm{m}^{2}$ & Excellent \\
\hline
\end{tabular}

\subsubsection{Best-performing WECS}

The key factor for the WECS election is its efficiency, commonly known as Capacity Factor or $C F$. $C F$ is described by $\mathrm{M}$. Bencherif et al [14] as the ratio between the output energy and the maximum available energy converted by a WECS running at constant design efficiency. In order to find the CF, eq. (7), (8) and (9) [9] are used.

$h_{v}=f_{v} * h_{a}$

Here $h_{v}=$ Hours per year in which a wind speed $v$ is available (h), $f_{v}=$ Relative frequency of each wind speed $v(\%)$ and $h_{a}$ $=$ Hours per year: $8760(\mathrm{~h})$.

$$
E_{v}=P_{v}^{*} h_{v}
$$

Here $E_{i}=$ Energy produced at a wind speed $v(\mathrm{Wh})$ and $\mathrm{PV}=$ Output power at a wind speed $v(\mathrm{~W}) . p_{v}$ is given by the WECS power curve (WTPC).

$$
E_{a}=\sum_{v=1}^{k} E_{v}
$$

Here $E_{a}=$ Annual energy production of the WECS (Wh), $E_{v}$ $=$ Energy produced at a wind speed $v(\mathrm{Wh}), v=1=$ Minimum wind speed value $(\mathrm{m} / \mathrm{s})$ and $v=k=$ Maximum wind speed value $(\mathrm{m} / \mathrm{s})$. The equivalent hours are calculated by (10) and represent the number of hours that the WECS would hypothetically be operating at their rated power for one year.

Based on this, the Factor of capacity of the WECS (11) is determined [9].

$$
h_{\text {eq }}=\frac{E_{a}}{P_{\text {rated }}}
$$

$$
C F=\frac{h_{e q}}{h_{a}}
$$

Here $h_{e q}=$ Equivalent hours (h), $C F=$ Capacity Factor $(-)$, $E_{a}=$ Annual energy generated by WECS $(\mathrm{kWh}), P_{\text {rated }}=$ Rated power of the WECS $(\mathrm{kW})$ and $h_{a}=$ Hours per year $(\mathrm{h})$. The $C F$ value must be greater than $20 \%$ to consider a system preliminarily feasible for electric generation, whether it is just a single turbine or a wind farm [15].

\subsection{Economic aspects}

A brief economic analysis evaluates each WECS option. The economic analysis is based on the economic costs of the system (batteries, WECS and installation) and the revenues from selling the generated energy to the market. Other considerations as transportation, land costs, maintenance, taxes, subsidies or legal incentive were not taken into account for this project.

\subsubsection{Battery capacity}

Usually, for the NCRE which are based on intermittent energy sources a battery bank is needed, especially if the system requires to meet a community demand autonomously. Hence, battery banks are a key, technical and financial, consideration.

Considerations for the battery bank election are listed below:

-The data obtained from the annual generated energy (MWh/year) of each WECS must be converted to Wh.

-The battery type for this study is the stationary $\mathrm{Pb} / \mathrm{Acid}$.

-The maximum depth of occasional discharge and the permissible daily discharge depth, are 0,6 and 0,2 respectively [16].

-The capacity of the battery bank depends on the days of autonomy offered to the user (3 days is typical) [17].

-In general, voltages of $12 \mathrm{~V}$ are recommended for powers of less than $1,5 \mathrm{~kW}, 24$ or $48 \mathrm{~V}$ for powers between 1,5 and 5 $\mathrm{kW}$ and 48 or $120 \mathrm{~V}$ for powers greater than $5 \mathrm{~kW}$, since 


\section{TECCIENCIA}

these last ones require a bank of batteries that allow to discharge slowly during a long period of time. A set of 48 volts batteries is selected [18].

Selecting the battery bank is defined by the following steps

a) Energy accumulated in a set

The energy accumulated in a set is given by eq. (9):

$$
E=C_{b} * V_{b}
$$

Here $E=$ Energy accumulated in a set (Wh), $C_{b}=$ Capacity in Ah of the set and $V_{b}=$ Voltage of the set (V).

b) Daily consumption

$$
C_{d}=\frac{E_{d}}{V_{b}}
$$

Here $C_{d}=$ Daily consumption (Ah), $E_{d}=$ Energy needed for 24 hours a day (Wh) and $V_{b}=$ Voltage of the set (V).

c) Size of the accumulator

$$
C_{b}=\frac{C_{d} * D_{a}}{P_{f}}
$$

Here $C_{b}=$ Size of the accumulator (Ah), $P_{f}=$ Maximum depth of occasional discharge $=0,6, C_{d}=$ Daily consumption $(\mathrm{Ah})$ and $D_{a}=$ Days autonomy.

d) Permitted Daily Discharge Test

$$
C_{b} \geq \frac{C_{d}}{D_{p f}}
$$

Here $C_{b}=$ Size of the accumulator (Ah), $D_{p f}=$ Permissible daily discharge depth=0,2 and $C_{d}=$ Daily consumption (Ah).

\subsection{WECS costs}

The costs of the system is: Turbine/generator, Inverter, Diode, regulator, rectifier and tower. Values for these items are obtained from the manufacturer catalog.

\subsection{Economic viability considerations}

Economic viability is based on the relation between costs and revenues. The main drawback for WECS projects is the initial investment, which represents a very large sum of money for any investor and a very low internal rate of return (IRR) value, which would be the interest rate at which the net present value (NPV) becomes zero. Usually an IRR over $20 \%$ represents a rentable project.

Although there is a high initial cost of installing a park wind farm, WECS presents important benefits: a low maintenance frequency, estimated life the components, daily operation, and maintenance easy to carry out .

IRR is the key factor as it is the most common and reliable consideration for economic evaluation. To find IRR, it is needed to obtain the annual cash flow, given an estimated of 15 years of life for the project.

The principal variables for the economic analysis are listed below.

- Total costs of the project.

- Net energy output of the system (annual base).

- Price of the energy $(404,75 \$ / \mathrm{kWh}$.) [19].

- Inflation (4\% annually) years [20].

- Costs of connection to the grid: wiring, substationcand necessary power lines (9-14\% of total costs [21]).

- A lifespan of 15 years for the batteries.

\section{Technical evaluation}

The location of the study is the small town of Berlin, in the municipality of Tona - Santander. Berlin was selected since, and according to IDEAM data [22] and ESSA EPM previous studies [23], it has an appreciable wind potential and continuity as well as a large and reliable database.

Berlin is in the northeast of Colombia, $63 \mathrm{~km}$ away from the department capital, at $3200 \mathrm{~m}$ a.s.l and an average temperature is $9.2^{\circ} \mathrm{C}$. The principal economic activity is the agriculture, and its territory is mostly composed by moorland.

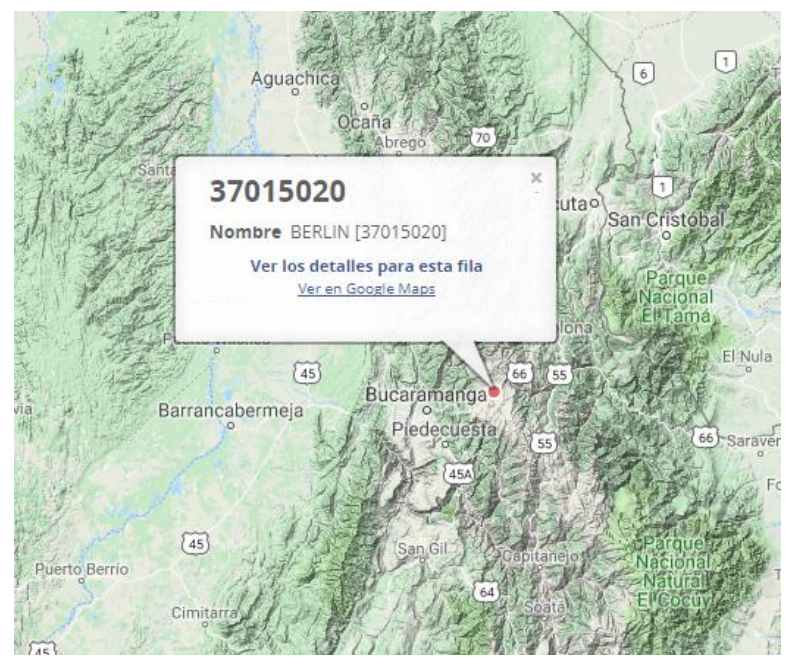




\section{TECCIENCIA}

Figure 2 Geographical location of the Berlin meteorological station, Santander - Colombia [22].

Table 2 Average wind speed.

\begin{tabular}{lr}
\hline Month & $\begin{array}{r}\text { Average wind } \\
\text { speed }(\mathrm{m} / \mathrm{s})\end{array}$ \\
\hline \hline January & 4,43 \\
February & 3,33 \\
March & 3,15 \\
April & 3,88 \\
May & 4,91 \\
June & 6,34 \\
July & 5,83 \\
August & 5,16 \\
September & 4,46 \\
October & 3,36 \\
November & 3,16 \\
December & 4,55 \\
\hline
\end{tabular}

Table 3 Berlin data at the site station.

\begin{tabular}{lrl}
\hline \hline Density & $1,8296 \mathrm{~kg} / \mathrm{m}^{3}$ \\
Average wind speed & $4,484 \mathrm{~m} / \mathrm{s}$ \\
Wind speed standard deviation & $2,751 \mathrm{~m} / \mathrm{s}$ \\
\hline
\end{tabular}

Table 4 Weibull parameters.

\begin{tabular}{lll}
\hline \hline$K$ & $1,700-$ \\
$n$ & $1,588-$ \\
Gamma & $0,892-$ \\
$A$ & $5,026 \mathrm{~m} / \mathrm{s}$ \\
\hline
\end{tabular}

Data was collected from the meteorological station 37015020 , property of IDEAM, at 3214 masl and located at $7^{\circ} 11^{\prime} 13$ North latitude and $72^{\circ} 52^{\prime} 07$ West longitude of the meridian of Greenwich (approx. $1 \mathrm{~km}$ from Berlin's municipal seat), as shown in Figure 2

The database provided directly by the IDEAM counts with a daily measurement of wind speed in 2015, which is summarized in Table 2.

From the location data (temperature, altitude and wind speeds) site density of the air, average wind speed and wind speed standard deviation are calculated. Results are showed in Table 3.

According to IDEAM [24], wind speeds with intensities equal or greater than $5 \mathrm{~m} / \mathrm{s}$ provide an alternative for energy use and, as observed in Table 3, the average wind speed of Berlin is below that value. However, wind speeds are not the only parameter. Velocities' frequency of occurrence is also a key factor to determine the viability of any wind project.

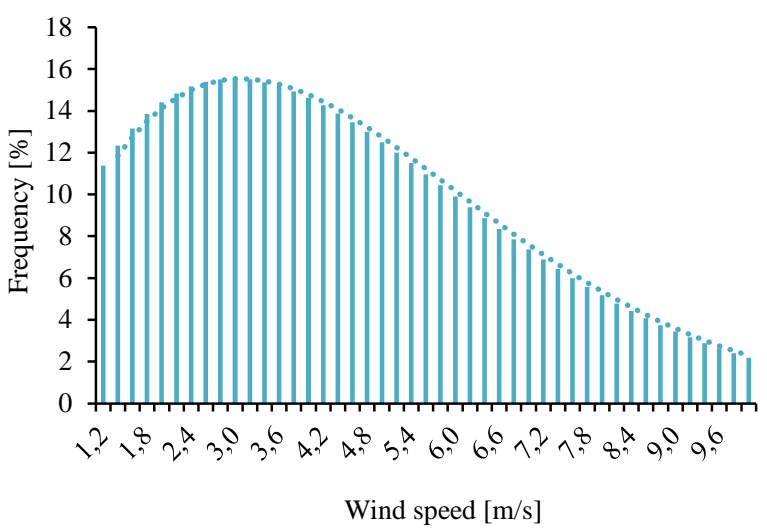

Figure 3 Weibull distribution curve.

The parameters for the Weibull function are described in Table 4. As shown in the Weibull distribution curve (Fig. 3), the predominant speeds in Berlin are close to $3 \mathrm{~m} / \mathrm{s}$, much lesser than the recommended by IDEAM [24].

From eq. (6), available wind potential of Berlin is 649,924 $\mathrm{W} / \mathrm{m} 2$, a "good" potential according to the criteria in Table 1. Hence, even though the wind speeds are relatively low, the potential of the site determines its possibility to realize small wind power projects using low-power wind turbines.

To select an appropriate WECS, it is important to consider the cut-in wind speed (wind speed at which the turbine will start to generate electricity) to take advantage of the maximum possible hours per day. The cut-in wind speed of the WECS selected must match the range of velocities with greater frequency of occurrence from the Weibull distribution (Fig. 3) [25].

Two low-power WECS are considered for this study. SWG of $1 \mathrm{~kW}$ [26] and IT-Zefiro of $3 \mathrm{~kW}$ [27]. Also, the ENERCON E-44 of $900 \mathrm{~kW}$ [28], a medium-power WECS is integrated to the options in order to analyze the different results between the comparison of the low-power WECS with the medium-power one.

The specification of each turbine and their technical characteristics are shown in Fig 4, 5, 6 and Table 5, 6, 7. Results from the technical evaluation for each turbine are shown in Table 8.

E-44 WECS has the higher net power output (482.93 $\mathrm{MWh} /$ year) between the three options. However, it also presents the lower FC as it requires a higher cut-in speed than the other options. Therefore, the E-44 WECS is the least 


\section{TECCIENCLA}

efficient option for the project. IT-Zefiro WECS has the higher factor of capacity, 33,44\%, considering its FC is over $20 \%$, IT-Zefiro WECS is the best technical option for the project.

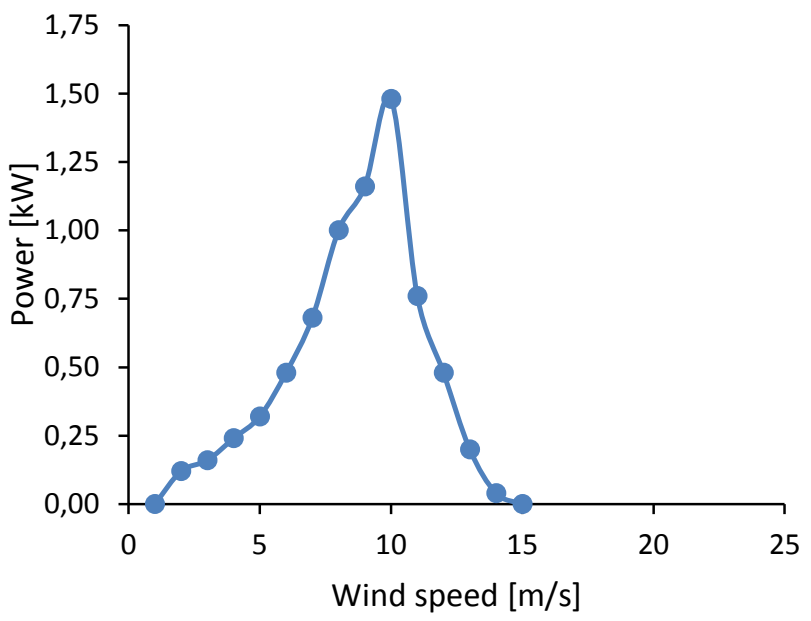

Figure 3 Power curve SWG [26].

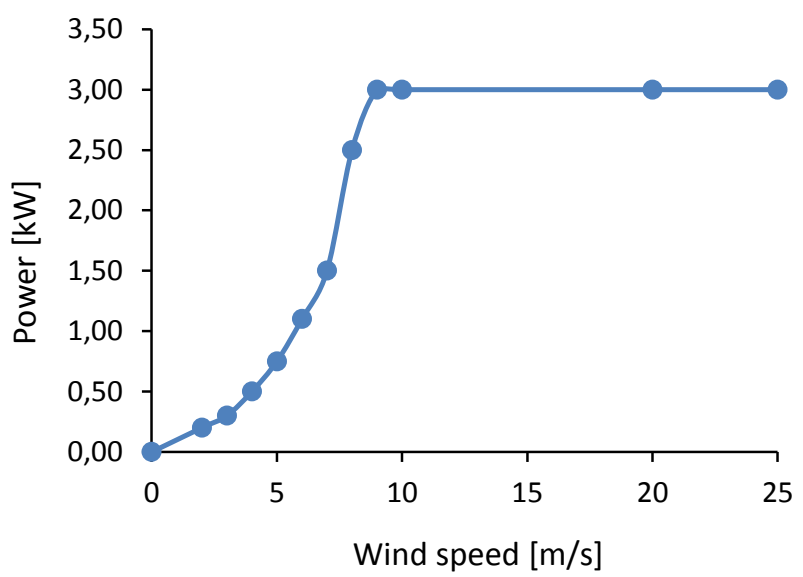

Figure 5 Power curve IT-Zefiro [27].

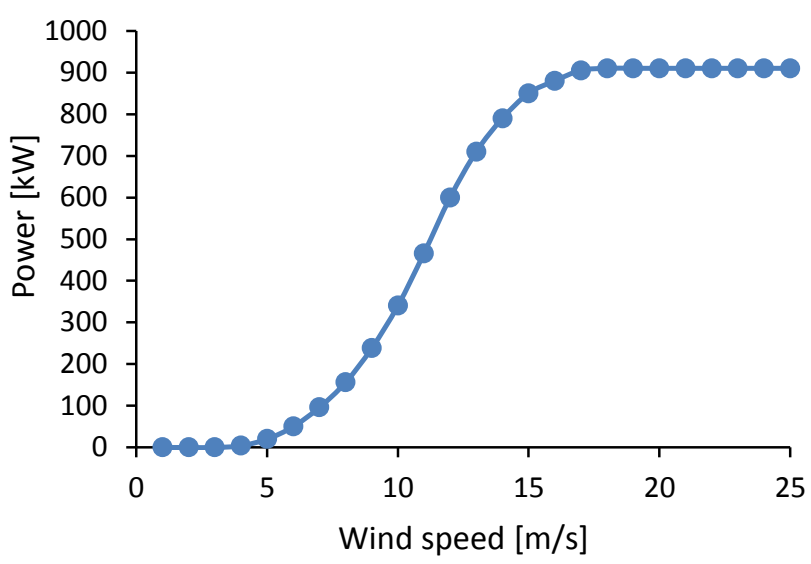

Figure 4 Power curve E-44 [28].

Table 5 Technical specifications SGW.

\begin{tabular}{ccc}
\hline \hline Rated power & 1 & $\mathrm{~kW}$ \\
Hub height & 6 & $\mathrm{~m}$ \\
Rotor diameter & 2,7 & $\mathrm{~m}$ \\
Cut-in wind speed & 2 & $\mathrm{~m}$ \\
\hline
\end{tabular}

Table 6 Technical specifications IT-Zefiro.

\begin{tabular}{ccc}
\hline \hline Rated power & 3 & $\mathrm{~kW}$ \\
Hub height & 12,5 & $\mathrm{~m}$ \\
Rotor diameter & 3,6 & $\mathrm{~m}$ \\
Cut-in wind speed & 1,5 & $\mathrm{~m}$ \\
\hline
\end{tabular}

Table 7 Technical specifications E-44.

\begin{tabular}{cccc}
\hline Rated power & 900 & $\overline{\mathrm{kW}}$ \\
Hub height & & 45 & $\mathrm{~m}$ \\
Rotor diameter & & 44 & $\mathrm{~m}$ \\
Cut-in wind speed & & 3.0 & $\mathrm{~m}$ \\
\hline
\end{tabular}

Table 8 Energy generation for each WECS.

\begin{tabular}{ccccc} 
WECS & SWG & IT-Zefiro & E-44 \\
\hline \hline Rated Power (kW) & 1 & & 300 & 900 \\
Equivalent hours (h) & 2325 & 2930 & 537 \\
Factor of capacity (\%) & 26,54 & 33,44 & 6,13 \\
Annual production & 2,32 & 8,79 & 482,93 \\
(MWh/year) & & & \\
\hline
\end{tabular}

Table 7 Battery capacity. 


\section{TECCIENCLA}

$\begin{array}{lllll}\begin{array}{l}\text { Size } \quad \text { of } \\ \text { accumulator (Ah) }\end{array} & \text { the } & 750 & 2500 & 140000\end{array}$

\section{Economic evaluation}

Economic considerations comprehend the costs of the project and the revenues from selling the energy generated by the system. The battery set is compound by $\mathrm{Pb} / \mathrm{acid}$ batteries operating at a nominal voltage of $24 \mathrm{~V}$, the total size of the accumulator is shown in Table 9 for each WECS. WECS related costs for each option are listed in Table 10. Considering the result of the cash flow analysis, the best WECS, ergo, the one with higher IRR is the IT-Zefiro. Although, its IRR value (10\%) it is not especially high compared to private investment requirements (20-30\% needed). The cash flow and IRR of the different options are shown in Table 11.

Table 8 System elements [29][30][31][32][33][34][35].

\begin{tabular}{|c|c|c|c|c|c|c|}
\hline ELEMENT & \multicolumn{2}{|c|}{ PRICE SWG (COP) } & \multicolumn{2}{|c|}{ PRICE IT ZEFIRO (COP) } & \multicolumn{2}{|c|}{ PRICE E-44 (COP) } \\
\hline WECS & $\$$ & $14.100 .000,00$ & $\$$ & $21.855 .000,00$ & $\$$ & $4.880 .407 .514,16$ \\
\hline Inverter & $\$$ & $2.820 .433,00$ & $\$$ & $4.440 .840,00$ & $\$$ & $7.744 .350,00$ \\
\hline $\begin{array}{r}\text { Diode regulator and } \\
\text { rectifier }\end{array}$ & $\$$ & $294.476,44$ & $\$$ & $449.700,00$ & $\$$ & $1.197 .000,00$ \\
\hline Battery bank & $\$$ & $1.196 .310,00$ & $\$$ & $3.343 .920,00$ & $\$$ & $328.666 .770,00$ \\
\hline Tower & $\$$ & $1.887 .600,00$ & $\$$ & $2.098 .800,00$ & $\$$ & $18.473 .100,00$ \\
\hline $\begin{array}{r}\text { Installation (wiring, } \\
\text { etc.) }\end{array}$ & $\$$ & $1.826 .893,75$ & $\$$ & $2.896 .943,40$ & $\$$ & 471.283.986,07 \\
\hline Subtotal & $\$$ & $22.125 .713,19$ & $\$$ & $35.085 .203,40$ & $\$$ & $5.707 .772 .720,23$ \\
\hline Unforeseen $10 \%$ & $\$$ & $2.212 .571,32$ & $\$$ & $3.508 .520,34$ & $\$$ & 570.777.272,02 \\
\hline Total investment & $\$$ & $24.338 .284,51$ & $\$$ & $38.593 .723,74$ & $\$$ & $6.278 .549 .992,26$ \\
\hline
\end{tabular}

Table 9 Estimation of the internal rate of return.

\begin{tabular}{c|r|r|r}
\hline \hline \multirow{2}{*}{ CONCEPT } & \multicolumn{1}{c|}{ CASH FLOW- } & \multicolumn{1}{c}{ CASH FLOW- IT } & \multicolumn{1}{c}{ CASH FLOW- } \\
\hline \hline (I) Investment & $-24.338 .284,51$ & $-38.593 .723,74$ & $-6.278 .549 .992,26$ \\
$\mathrm{Q}_{1}$ & $939.018,61$ & $3.557 .747,23$ & $195.465 .627,74$ \\
$\mathrm{Q}_{2}$ & $976.579,35$ & $3.700 .057,12$ & $203.284 .252,85$ \\
$\mathrm{Q}_{3}$ & $1.015 .642,53$ & $3.848 .059,40$ & $211.415 .622,97$ \\
$\mathrm{Q}_{4}$ & $1.056 .268,23$ & $4.001 .981,78$ & $219.872 .247,88$ \\
$\mathrm{Q}_{5}$ & $1.098 .518,96$ & $4.162 .061,05$ & $228.667 .137,80$ \\
$\mathrm{Q}_{6}$ & $1.142 .459,71$ & $4.328 .543,49$ & $237.813 .823,31$ \\
$\mathrm{Q}_{7}$ & $1.188 .158,10$ & $4.501 .685,23$ & $247.326 .376,24$ \\
$\mathrm{Q}_{8}$ & $1.235 .684,43$ & $4.681 .752,64$ & $257.219 .431,29$ \\
$\mathrm{Q}_{9}$ & $1.285 .111,80$ & $4.869 .022,74$ & $267.508 .208,55$ \\
$\mathrm{Q}_{10}$ & $1.336 .516,28$ & $5.063 .783,65$ & $278.208 .536,89$ \\
$\mathrm{Q}_{11}$ & $1.389 .976,93$ & $5.266 .335,00$ & $289.336 .878,36$ \\
$\mathrm{Q}_{12}$ & $1.445 .576,01$ & $5.476 .988,40$ & $300.910 .353,50$ \\
$\mathrm{Q}_{13}$ & $1.503 .399,05$ & $5.696 .067,93$ & $312.946 .767,64$ \\
$\mathrm{Q}_{14}$ & $1.563 .535,01$ & $5.923 .910,65$ & $325.464 .638,34$ \\
$\mathrm{Q}_{15}$ & $429.766,41$ & $2.816 .947,08$ & $9.816 .453,88$ \\
$\mathrm{Q}_{16}$ & $1.626 .076,41$ & $2.929 .624,96$ & $10.209 .112,03$ \\
$\mathrm{Q}_{17}$ & $1.691 .119,46$ & $3.046 .809,96$ & $10.617 .476,51$ \\
$\mathrm{Q}_{18}$ & $1.758 .764,24$ & $3.168 .682,36$ & $11.042 .175,57$
\end{tabular}




\begin{tabular}{r|r|r|r}
$\mathrm{Q}_{19}$ & $1.829 .114,81$ & $3.295 .429,65$ & $11.483 .862,60$ \\
$\mathrm{Q}_{20}$ & $1.902 .279,40$ & $3.427 .246,84$ & $11.943 .217,10$ \\
$\mathrm{Q}_{21}$ & $1.978 .370,58$ & $3.564 .336,71$ & $12.420 .945,78$ \\
$\mathrm{Q}_{22}$ & $2.057 .505,40$ & $3.706 .910,18$ & $12.917 .783,62$ \\
$\mathrm{Q}_{23}$ & $2.139 .805,62$ & $3.855 .186,59$ & $13.434 .494,96$ \\
$\mathrm{Q}_{24}$ & $2.225 .397,84$ & $4.009 .394,05$ & $13.971 .874,76$ \\
$\mathrm{Q}_{25}$ & $2.314 .413,76$ & $4.169 .769,81$ & $14.530 .749,75$ \\
$\mathrm{IRR}$ & $3 \%$ & $10 \%$ & $-6 \%$ \\
\hline \hline
\end{tabular}

\section{Conclusions}

Berlin counts with constant wind speeds close to $3 \mathrm{~m} / \mathrm{s}$ and an available wind potential of $649,924 \mathrm{~W} / \mathrm{m}^{2}$, which represents a good alternative for small-scale wind energy production in the Andean region of Colombia. Given the local conditions, the IT-Zefiro WECS of $3 \mathrm{~kW}$ is a feasible option for small-scale NCRE generation since it has a FC of $33,44 \%$ and its cut-in wind speed is $2 \mathrm{~m} / \mathrm{s}$, value that is between the speeds presented most frequently.

The economic feasibility is strongly influenced by the way in which the energy is valued in certain periods of the time. Therefore, from an economic point of view, the project is debatable for the SWG-1kW and IT Zefiro- $3 \mathrm{~kW}$ wind turbines since the IRR was positive but does not reach the requirements of many private investors. Medium-power wind generators as the E44-900 $\mathrm{kW}$ do not reach the minimum specification for generation of energy, nor a $\mathrm{CF}$ over $20 \%$ nor an IRR positive, discarding the option of wind generation other than small-scale.

Since the present project is just a preliminary study of the installation of a wind turbine in the Berlin area, it is recommended that future studies take into account costs of: feasibility studies, civil works, land costs, operation, maintenance, transportation etc. as well as policies, subsidies and economic requirements for public investments. Also, if it is considered the possibility of the project entering the Green Bond Market, the profitability would improve, since a project like this would reduce the emission of greenhouse gases.

\section{References}

[1] A. Spanjer, "Russian gas price reform and the EU-Russia gas relationship: Incentives, consequences and european security of supply," 2007.

[2] J. D. Hamilton, "Historical oil shocks," No. 16790, 2011.

[3] UPME, "Integración de las energías renovables no convencionales en Colombia," Colombia, 2015.

[4] SIEL, "Informe mensual de variables de generación y del mercado eléctrico colombiado," 2016.

[5] J. Dobias, "El fenómeno de El Niño y su impacto en la generación hidroeléctrica de Chixoy," 2015.
[6] J. P. Valencia Quintero, "Generación distribuida: Democratización de la energia eléctrica," Univ. Libr., 2008.

[7] S. Dean and B. Illowsky, "Sampling and Data: Frequency, Relative Frequency, and Cumulative Frequency," Saylor Academy, 2011. [Online]. Available: https://www.saylor.org/site/wp-content/uploads/2011/06/MA1211.1.3-3rd.pdf.

[8] A. Ilinca, E. McCarthy, J.-L. Chaumel, and J.-L. Rétiveau, "Wind potential assessment of Quebec Province," Renew. Energy, vol. 28, no. 12, pp. 1881-1897, Oct. 2003.

[9] S. Cucó Pardillos, "Gestor de proyectos e instalaciones energéticas. Energías renovables, eficiencia y auditorías energéticas, diseño y explotación de instalaciones energéticas. Modulo Energía Eólica. Instalaciones Eólicas, Segunda ed. Edición. Instituto Tecnológico de la Energía (ITE), 2010.

[10] HBM Prenscia Inc., "Characteristics of the Weibull Distribution." [Online]. Available: http://www.weibull.com/hotwire/issue14/relbasics14.htm. [Accessed: 27-Feb-2018].

[11] W. Álvarez, L. Martínez, and A. Alvarado, "Aplicación de la ecuación de Weibull para determinar el potencial eólico en TunjaColombia," Perú, 2013.

[12] A. Parajuli, "A Statistical Analysis of Wind Speed and Power Density Based on Weibull and Rayleigh Models of Jumla, Nepal," Nepal. Energy Power Eng., vol. 8, no. 8, pp. 271-282, 2004.

[13] J. Manwell and et al., Wind Energy Explained. Great Britain Chippenham-Wiltshire, 2011

[14] M. Bencherif, "Optimum Selection of Wind Turbines," Sci. J. Energy Eng., vol. 2, no. 4, p. 36, 2014.

[15] C. Moreno Figueredo and et al., Diez respuestas y preguntas sobre energía eólica. CUBASOLAR, 2007.

[16] E.U.I.T.I Toledo, "Diseño y dimensionado de una instalación fotovoltaica." [Online]. Available: http://studylib.es/doc/88959/instalaciones-fotovoltaicas-enviviendas. [Accessed: 28-Feb-2018].

[17] CORPORACIÓN EMA, "Determinación de inversiones y gastos de administración, operación y mantenimiento para la actividad de generación en zonas no interconectadas utilizando recursos no renovables," 2012.

[18] M. Alonso Abella, "Dimensionado de Sistemas Fotovoltáicos," E.U.I.T.I Toledo.

[19] ESSA, "Tarifas ESSA 2017," 2017.

[20] Banco de la República de Colombia, "Indicadores de inflación básica y su variación anual.” [Online]. Available: http://www.banrep.gov.co/es/inflacion-basica. [Accessed: 28Feb-2018].

[21] CORPORACIÓN EMA, "Inversiones y gastos de AOM para la actividad de generación en zonas no interconectadas utilizando recursos renovables," 2012

[22] IDEAM, "Catálogo Estaciones IDEAM." [Online]. Available: https://www.datos.gov.co/Ambiente-y-DesarrolloSostenible/Catalogo-Estaciones-IDEAM/n6vw-vkfe/data. [Accessed: 21-Feb-2018].

[23] ESSA EPM, "Proyecto piloto de generación Eólica en Santander," 2017. 


\section{TECCIENCIA}

[24] IDEAM, "Densidad de energía eólica a 20 y 50 metros de altura," in Atlas de Viento y Energía Eólica de Colombia, Colombia, p. 75.

[25] C. Carrillo, J. Cidrás, E. Díaz-Dorado, and A. Obando-Montaño, "An Approach to Determine the Weibull Parameters for Wind Energy Analysis: The Case of Galicia (Spain)," Energies, vol. 7, no. 12, pp. 2676-2700, Apr. 2014.

[26] Nohana3000, "Aerogeneradores $300 \mathrm{~W}, 500 \mathrm{~W}, 1 \mathrm{~kW}$ y 2 kW." [Online]. Available: http://www.nohana3000.com/wpcontent/uploads/5.Aerogeneradores-300-500-1-kw-y-2-kw.pdf. [Accessed: 26-Feb-2018].

[27] MIT, "Ficha técnica equipos minieólicos: ELIWIND*IT-Zefiro $3 \mathrm{kWp}, " 2013$.

[28] ENERCON, "ENERCON product overview," 2015. [Online]. Available: https://www.enercon.de/fileadmin/Redakteur/MedienPortal/broschueren/pdf/en/ENERCON_Produkt_en_06_2015.pdf. [Accessed: 26-Feb-2018].

[29] TEICAN, "Tarifa aerogeneradores y accesorios," 2012.

[30] Renewables First Ltd, "Introduction to Farm Wind Turbines / Medium-wind Turbines," 2011.

[31] Revosolar, "Inversores/Cargadores." [Online]. Available: http://www.revosolar.com/tienda-online-solar/es/18-inversorescargadores. [Accessed: 27-Feb-2018].

[32] Link Media Agency, "Controladores, rectificadores, reguladores de carga." [Online]. Available: http://www.lmagency.biz/contents/es/d15.html. [Accessed: 27Feb-2018].

[33] AutoSolar, "Baterías de GEL 48V." [Online]. Available: https://autosolar.es/baterias-gel-48v. [Accessed: 27-Feb-2018].

[34] SoloSotkcs, "Torre aerogenerador Bornay p 400 13mtrs." [Online]. Available: http://www.solostocks.com/ventaproductos/otros-productos-equipamiento-electrico/torre- aerogenerador-bornay-p-400-13mtrs-24555906. [Accessed: 27Feb-2018].

[35] R. Di Paolo, "Los costos de instalación de un parque eólico," 2017. [Online]. Available: https://www.sololocal.info/index.php/noticias/3224-los-costosde-instalacion-de-un-parque-eolico. [Accessed: 27-Feb-2018]. 